\title{
Phonological Modification on Teachers' Instructional Talk for Secondary School Students
}

\author{
Maemuna Muhayyang \\ English Department \\ Faculty of Languages and Literature \\ Universitas Negeri Makassar \\ Makasar, Indonesia \\ maemarasyid@yahoo.co.id
}

\begin{abstract}
This paper highlights the phonological modification of teachers' instructional talk in teaching English to secondary school students in South Sulawesi. The descriptive qualitative method was employed involving 10 English teachers teaching at ten different secondary schools. This study implemented direct classroom observation entailing videotape recording. This study found that the teachers modified their instructional talk into some Bahasa Indonesia sounds on either English vowels or consonants, in the beginning, during, and closing phases of teaching. Regarding English vowels, the modification mostly occurred on the front, central, and back vowels. The frequent modified in presenting teaching materials were the alveolar and velar plosive ( $t, d, k$, and $g$ ), dental and alveolar fricative $/ \theta, \delta, s$, and $\mathrm{z}) /$, palato alveolar fricative ( $\int$ and 3$)$, and palato alveolar affricative ( $t \int$ and $d z$ ). That modification, in short, bridged the teachers to talk in English as to make the students readily perceive the points of their presentation.
\end{abstract}

Keywords—phonological modification; instructional talk; vowels; and consonants

\section{INTRODUCTION}

Efforts on English language teaching in Indonesia are then mainly generated from and intended for the effectiveness of classroom interaction, in the sense that students who learn English as a foreign language are expected to benefit from the classroom interactions both practicing and using the language. For a start, the EFL students will get language input which also functions as the model from their teacher talk. In line with the use of classroom interaction, Krashen stated that the primary function of a second language class is to provide students with excellent comprehensible input that is unavailable to them on the outside and to bring them to the point where they can obtain comprehensible input on their own in the real world [1]. From this starting point, the students will creatively develop their English throughout their learning the language. However, speaking of the effectiveness of EFL classroom, the EFL students will most of the time face considerable hindrances in learning English as a foreign language.

There are many causes for this apprehensive condition coming on the surface. At present, at the university level, the phenomena in question are the language input in the forms of instructional and management talks. Regarding students' language development undertaken in the formal educational background, EFL teachers play important roles as language input providers and language models to be imitated by the students in teaching and learning processes. It cannot be denied that a teacher in teaching carries out some specific communicative acts such as lecturing, explaining, asking and responding questions, giving instruction or direction. These activities will inevitably facilitate the students to perform the same or similar things in communicating with each other accordingly.

On the contrary, when such instructional language is rarely or never performed and efficiently undertaken by teachers, the students' English achievement will be low as a result. Some questions may appear calling for answers why they occur. The answers, of course, may vary because of many influencing factors such as a teacher, students, material, and context of time and place. Often, of all the factors mentioned above, teachers, in this case, will become the main target of criticism. Therefore, teacher talk should deal with a good classroom management in the form of place context. If the EFL classroom is well organized, the best learning atmosphere can be created to facilitate the students to learn the language. It makes sense that the teacher can help students use language more effectively and productively by organizing a physical setting, focusing on the form and function of language, implementing flexible language learning groups, and employing questioning strategies that stimulate students' high order thinking and talking.

A teacher viewed from the task to carry out in the classroom plays three interrelated roles namely, managerial, instructional, and investigating roles. The managerial role is the total of the many attitudes and behaviors that a teacher employs to create the best possible condition under which learning can take place. The primary function of the EFL teacher in this managerial role is to motivate the students who are de-motivated and to nurture those who are already wellmotivated to the task of EFL learning. The instructional role of an EFL teacher described as the goal-oriented, task-dependent, and knowledge-based role in which he performs various things to facilitate the students learning, e.g., a teacher as a language use model is required to give such as the correct model of pronunciation, and sentence construction. The investigating role of an EFL teacher is meant to develop and enhance the 
effectiveness of the managerial and instructional roles. An EFL teacher should investigate, for example, the classroom climate, the preferred group work patterns, and who likes what and who likes whom.

The functional adjustment also characterizes the teacher's language as an input to the students. In line with language adjustment, Chaudron stated that teacher talk contains linguistic modifications or adjustments regarding phonology, lexicon, syntax, and discourse [2]. In the level of phonology, the teacher talk adjustment is typically slowing down the rate of speech, separating words or syllables articulation, using more careful pronunciation with more substantial stress, and increasing volume of keywords. In the level of the lexicon, the modifications are using limited vocabulary size, replacing the unfamiliar items, and repeating words. In the level of syntax, the modifications are generally regarding using fewer contractions, shorter utterances, making the grammatical relationship more explicit, and using co-ordinations more than subordination. He/she may merely make some repetitions, prompt, modeling, and expansion just to enable the students to use the most appropriate forms and functions of the language they are learning. It is clear that classroom holistically becomes the determinant factor toward the effective implementation of teaching methods as part of teachers' efforts to adopt language they use in teaching which suits their students' level of language competence.

\section{FOCUS AND PURPOSE OF THE STUDY}

About the teacher roles in teaching English as a foreign language, she has the mission to prepare and equip the students with reasonable competence and performance in EFL teaching covering all linguistic and nonlinguistic aspects of English. Therefore, the investigating point of this present study focuses on phonological modification of teachers' instructional talk in teaching English. In line with the case, the writer formulates the core question to be answered in this research (1) How do the teachers modify their instructional talk in teaching English? Therefore, the purpose of this study is to find the answer to the core question above, that is the way the teachers modify their instructional talk in teaching English.

\section{LITERATURE REVIEW}

\section{A. Teacher Talk in Foreign Language Classroom}

The language of the language teaching and learning is distinctive because it is designed for language learning to take place. An essential element in the success of foreign language learning appears to be how learners treated, the teaching method used with them, the language they hear, and the environment in which they are learning. The purpose of language teaching is providing the best input to the process of language learning. Everything the teacher does provide the learner with opportunities for encountering the language.

The teacher at this point may employ either communicative method or listening-based method. The communicative method emphasizes the learners' double role as listener and speaker. A typical exercise requires students to take both roles in conversation and not only to understand the information they are listening to but also to express it themselves. They are receiving input not only from the teacher but also from their peers in the class. The listening-based methods, on the other hands, confine the students to the role of listeners through the application of Total Physical Response, for instance, the students listen and carry out commands, but they do not need to speak. Hence the input they receive is wholly controlled by the teacher.

To make teacher talk as a comprehensible input to the students in classroom interaction, Cook proposed four critical things [3]. Firstly, be aware of the two levels at which language enters the classroom. Secondly, be aware of the different sources of input. Thirdly, the input that the students are getting is more than just sentences. The last is students learn from teaching not from learning.

At this point, the writer has come to the gist of this review by pooling the concept that teacher talk is the language produced by teachers addressed to the students in classroom interaction characterized by linguistic modifications or adjustments to facilitate the students to grasp the messages conveyed. Lecture talk categorized into instructional and management talks serving two functions that are pedagogical and social.

\section{B. The Characteristics of Teacher Talk in Classroom Interaction}

It is clear that teacher in foreign language classroom should supply the students with correct forms and functions of the language. Regarding the language used by the teacher in foreign language teaching and learning classroom, the teacher should meet with the five characteristics of good teaching presentation as follows:

1) The teacher talk should be explicit: This means that students should have no difficulty in understanding what the new language items mean. In this respect, the teacher should use simple language.

2) The teacher talk should be efficient: This means that the students can get the personalization stage to manipulate the new language items.

3) The teacher talk should be lively and exciting: This refers to the assumption that the students are directly interested in the teacher talk.

4) The teacher talk should be appropriate: This means that the teacher talk is meaningful and useful in communication and interaction either inside or outside the classroom.

5) The teacher talk should be productive: This indicates that the students can use the language for both the academic purposes and communicative purposes appropriately.

In conjunction with the characteristics of teacher talk, Breines describes ccharacteristics of teacher talk which function as a language input for the development of students' foreign language [4]. The characteristics are directive, imperative, shorter, simpler, slower, and more precise speech and repetition. 


\section{METHOD}

This study employed descriptive qualitative method aiming at describing the ways the teachers modify their instructional talk in three phases of teaching, that is before, during, and after teaching. Their instructional talk referring to the modification of language use in presenting their teaching materials covers both vowels and consonants of English. The data resources were 10 English teachers teaching at ten different secondary schools in South Sulawesi, Indonesia.This study applied direct classroom observation entailing videotape recording was the primary instrument to obtain the data on the ways the teachers modify their instructional talk covering vowels and consonants of English in three phases of teaching, that is before, during, and after teaching.

\section{RESULTS AND DISCUSSION}

The data analysis gained through the direct classroom observation showed that the ten teachers modified their instructional talk into some Bahasa Indonesia sounds correspond to both English vowels and consonants in the beginning, during, and closing phases of teaching. Regarding English vowels, the modification generally occurred in pure vowels consisting of front vowels, central vowels, and back vowels. The modification also accured in diphthongs consisting of sounds /ei/, /ia/, /ai/, /au/, and /ou/. Thus, the modification also reached alveolar and velar plosive $(\mathrm{t}, \mathrm{d}, \mathrm{k}$, and $\mathrm{g}$ ), dental and alveolar fricative $/ \theta$,, , s, and z) $/$, palato alveolar fricative $\left(\int\right.$ and 3$)$, and palato alveolar affricative $\left(\mathrm{t} \int\right.$ and d3). The description of these findings are as in Table 1.

TABLE I. THE MisPRONUNCIATION OF PURE VOWELS

\begin{tabular}{|c|c|c|c|c|}
\hline \multirow[t]{2}{*}{ VOWEL } & \multirow{2}{*}{$\begin{array}{l}\text { VOWEL } \\
\text { SOUND }\end{array}$} & \multirow[t]{2}{*}{ WORDS } & \multicolumn{2}{|c|}{ PRONUNCIATION } \\
\hline & & & Incorrect & Correct \\
\hline Central & $/ a /$ & $\begin{array}{c}\text { Material } \\
\text { Social } \\
\text { Famous } \\
\text { Observe }\end{array}$ & $\begin{array}{l}\text { /material/ } \\
\text { /souf 1/ } \\
\text { /'feimes/ } \\
\text { /ob'zz:v/ }\end{array}$ & $\begin{array}{l}\text { /mo'tıərial/ } \\
\text { /'səof 1/ } \\
\text { /' feIməs/ } \\
\text { /əb'zz:v/ }\end{array}$ \\
\hline \multirow[t]{2}{*}{ Front } & $/ \mathrm{I} /$ & $\begin{array}{c}\text { Example } \\
\text { Written } \\
\text { Explain } \\
\text { Elaborate } \\
\text { Examination } \\
\text { Target }\end{array}$ & $\begin{array}{l}\text { /eg'za:m.pl/ } \\
\text { /'raitn/ } \\
\text { /ek'spleın/ } \\
\text { /e'læbrat/ } \\
\text { /eksemi'neI/n/ } \\
\text { /'ta:.get// }\end{array}$ & $\begin{array}{c}\text { /Ig'za:m.pl/ } \\
\text { /'ritn/ } \\
\text { /Ik' spleın/ } \\
\text { /I'læbbrot/ } \\
\text { /Ig. zæm..' 'neI/ } \\
\text { n/ } \\
\text { /'ta..git/ }\end{array}$ \\
\hline & /e/ & $\begin{array}{l}\text { Guest } \\
\text { Event }\end{array}$ & $\begin{array}{l}\text { /gast/ } \\
\text { /ivənt/ }\end{array}$ & $\begin{array}{l}\text { /gest/ } \\
\text { /I'vent/ }\end{array}$ \\
\hline \multirow{3}{*}{ Rounded } & $/ \mathrm{a}: /$ & Task & /task/ & /ta:sk/ \\
\hline & /o:/ & $\begin{array}{l}\text { Called } \\
\text { Source } \\
\text { Cause }\end{array}$ & $\begin{array}{l}\text { /kold/ } \\
\text { /sors/ } \\
\text { /koz/ }\end{array}$ & $\begin{array}{l}\text { /ko:ld/ } \\
\text { /ss:s/ } \\
\text { /ko:z/ }\end{array}$ \\
\hline & $/ \mathrm{w} /$ & $\begin{array}{c}\text { Involved } \\
\text { column }\end{array}$ & $\begin{array}{l}\text { /In' volv/ } \\
\text { /'koləm/ }\end{array}$ & $\begin{array}{l}\text { /Invplv/ } \\
\text { /'kplom/ }\end{array}$ \\
\hline Unrounded & $/ \mathfrak{a} /$ & Advertisement & /adv3:.taaz.mont/ & /'ædv3:tarzmənt/ \\
\hline
\end{tabular}

The table above shows the teachers' mispronunciation in pure vowel consisting of central vowel /o /, front vowel /I/ and /e/, rounded vowels /a:/, /o:/, and /p/ and 1 unrounded vowel /æ/. This mispronunciation simply indicates They modified the English vowel sounds into Indonesian ways of pure vowels or diphthongs articulation. This modification occurs since they might not possess good theoretical background knowledge of English Phonology or it might be the influence of their local or mother tongue. This modification, however, bridged them to deliver their teaching materials in the frame of instructional and management talks during the three phases of teaching and learning English.

The instructional talk modification of the teachers not only appeared in pure English vowels described above but also in diphthongs exemplified in the following Table 2.

TABLE II. THE MISPRONUNCIATION OF DIPHTHONGS

\begin{tabular}{|c|c|c|c|}
\hline \multirow{2}{*}{ DIPHTHONGS } & \multirow{2}{*}{ WORDS } & \multicolumn{2}{|c|}{ PRONUNCIATION } \\
\hline & & Incorrect & Correct \\
\hline \multirow{2}{*}{ /ai/ } & Almighty & Al'migtI & s:l'mar.ti \\
\hline & Type & Tipe & taip \\
\hline /av/ & About & a'bot & a'baut \\
\hline \multirow{5}{*}{ /eI/ } & Amazing & Emai'zin & a'meizin \\
\hline & Information & Informesien & In.fə'meI. fən \\
\hline & Ladies & Ledis & 'ler.dis \\
\hline & Volcano & vulkano & vpl'keinəひ \\
\hline & Explain & Eksplen & Ik'splein \\
\hline /ov/ & Know & Now & nou \\
\hline
\end{tabular}

The table above shows the teacher's mispronunciation in diphthong which is consists of 3 words in diphthong /ei/, 1 word in diphthong /iə/, and 1 word in diphthong /ai/. This fact indicates that the teacher still did not know how to pronounce those words correctly.

TABLE III. THE TEACHER's MISPRONUNCIATION IN CONSONANT

\begin{tabular}{|c|c|c|c|c|}
\hline \multirow{2}{*}{$\begin{array}{c}\text { CON- } \\
\text { SONANT }\end{array}$} & \multirow[t]{2}{*}{ TOTAL } & \multirow[t]{2}{*}{ WORDS } & \multicolumn{2}{|c|}{ PRONOUNCE } \\
\hline & & & Wrong & Correct \\
\hline $\begin{array}{c}\text { Alveolar } \\
\text { Plosive /t/ }\end{array}$ & 1 & Expert & /'ek.sp3r/ & /'ek.sp3:t/ \\
\hline $\begin{array}{c}\text { Alveolar } \\
\text { Fricative /z/ }\end{array}$ & 2 & $\begin{array}{c}\text { Use } \\
\text { Analyze }\end{array}$ & $\begin{array}{c}\text { /ju:s/ } \\
\text { /'æn. ə l.ais/ }\end{array}$ & $\begin{array}{c}\text { /ju:z/ } \\
\text { /'æn. ə l.aız/ }\end{array}$ \\
\hline $\begin{array}{c}\text { Palate } \\
\text { Alveolar } \\
\text { Fricative / } /\end{array}$ & 1 & English & /'in.glis/ & /'in.glif/ \\
\hline $\begin{array}{c}\text { Palatal } \\
\text { Approximant } \\
\text { /j/ }\end{array}$ & 1 & Education & $\begin{array}{c}\text { /,edv'ker. } \int \partial \\
\mathrm{n} /\end{array}$ & /,ed.ju'keı.fə n/ \\
\hline $\begin{array}{c}\text { Velar Plosive } \\
\text { /k/ }\end{array}$ & 1 & Architecture & /'a:.sI.tek.tfər/ & /'a:.kI.tek.tfər/ \\
\hline
\end{tabular}

The Table 3 above shows the teacher's mispronunciation in a consonant. It consists of 1 alveolar plosive /t/, 2 alveolar 
fricatives /z/, 1 palate alveolar fricative /S/, 1 palatal approximant $/ \mathrm{j} /$ and 1 velar plosive $/ \mathrm{k} /$. Mostly teacher did some mispronunciation in using alveolar fricative $/ \mathrm{z} /$ by changing /z/ into /s/ (see table 1). It might happen because the teacher did not know the correct pronunciation of teacher using the words repeatedly during teaching and learning process.

TABLE IV. THE TEACHER'S MiSPRONUNCIATION IN WORD STRESS

\begin{tabular}{|l|l|l|}
\hline \multirow{2}{*}{ WORD } & \multicolumn{2}{|c|}{ MISPRONUNCIATION IN WORD } \\
& \multicolumn{2}{|c|}{ STRESS } \\
\cline { 2 - 3 } & \multicolumn{1}{|c|}{ 'Erong } & \multicolumn{1}{c|}{ Correct } \\
\hline Event (n) & 'Authorities & E'vent \\
Authorities (n) & Au'thorities \\
Police (n) & Po'lice & 'Police \\
Contain (n) & Con'tain & 'Contain \\
Paragraph (n) & Parag'raph & 'Pharagraph \\
Correct (Adj) & Co'rrect & 'Correct \\
Research (n) & Re'search & 'Research \\
Architecture (n) & Architec'ture & Ar'chitecture \\
Interview (v) & Inter'view & 'Interview \\
Comment (n) & Co'mment & 'Comment \\
\hline
\end{tabular}

The Table 4 above indicates that there are several mispronunciations in word stress pronounced by the total teacher's talk. The teacher mostly produced the word stress for noun meanwhile the word stress should be in the verb, for instance, the teacher said co'rrect for noun instead of 'correct as the right one for a noun. The mispronunciation in word stress is commonly found for some teachers with a particular accent or dialect from their first language.

\section{References}

[1] S. D. Krashen, Inquiries \& insights: second language teaching: immersion \& bilingual education, literacy. Alemany Press, 1985.

[2] C. Chaudron, Second language classrooms: Research on teaching and learning. Cambridge University Press, 1988.

[3] V. Cook, Second language learning, and language teaching. Routledge, 2013.

[4] H. Takahashi-Breines, "The role of teacher-talk in a dual language immersion third-grade classroom," Billing. Res. J., vol. 26, no. 2, pp. 461-483, 2002. 